\title{
Cordonnier Grade 1 Bacterial Complication, Outpatient Treatment Bacterial Focus
}

National Cancer Institute

\section{Source}

National Cancer Institute. Cordonnier Grade 1 Bacterial Complication, Outpatient

Treatment Bacterial Focus. NCI Thesaurus. Code C138293.

Any bacterially-focused infection treated as an outpatient (e.g., urinary tract infection, ang ina), excluding any form of bronchopneumonia. 